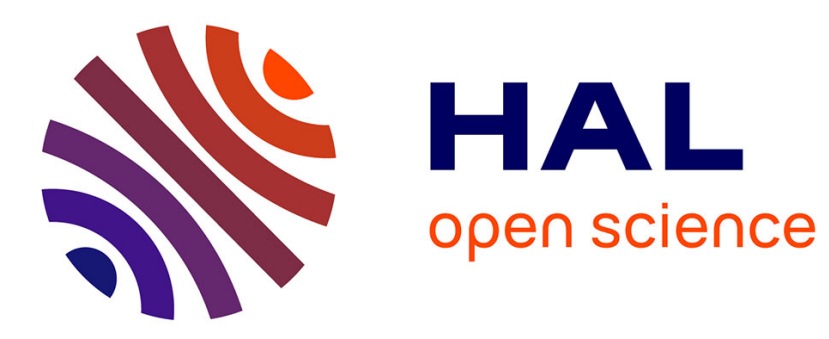

\title{
Safety and Impact of Nasal Lavages During Viral Infections Such as SARS-CoV-2
}

Thomas Radulesco, Jerome R Lechien, Sven Saussez, Claire Hopkins, Justin Michel

\section{- To cite this version:}

Thomas Radulesco, Jerome R Lechien, Sven Saussez, Claire Hopkins, Justin Michel. Safety and Impact of Nasal Lavages During Viral Infections Such as SARS-CoV-2. Ear Nose and Throat Journal, 2021, 100 (2 supp), pp.188S-191S. 10.1177/0145561320950491 . hal-03198711

\section{HAL Id: hal-03198711 \\ https://hal.science/hal-03198711}

Submitted on 15 Apr 2021

HAL is a multi-disciplinary open access archive for the deposit and dissemination of scientific research documents, whether they are published or not. The documents may come from teaching and research institutions in France or abroad, or from public or private research centers.
L'archive ouverte pluridisciplinaire HAL, est destinée au dépôt et à la diffusion de documents scientifiques de niveau recherche, publiés ou non, émanant des établissements d'enseignement et de recherche français ou étrangers, des laboratoires publics ou privés. 


\title{
Safety and Impact of Nasal Lavages During Viral Infections Such as SARS-CoV-2
}

\author{
Thomas Radulesco, MD, PhD, MS ${ }^{1,2} \oplus$, Jerome R. Lechien, MD, PhD, MS ${ }^{1,3,4} \oplus$, \\ Sven Saussez, MD, $P h D, M^{3}{ }^{3}$, Claire Hopkins, $M D, P^{2} D^{5}$, \\ and Justin Michel, MD, PhD, MS ${ }^{1,2}$
}

\begin{abstract}
Keywords
Much has been stated about the potential risks of nasal lavages (NL) during the coronavirus disease 2019 (COVID-19) pandemic for COVID-19 patients and surrounding people. Several otolaryngological societies recommended to limit NL, supposing it may be associated with viral spread to lower airway. ${ }^{1} \mathrm{On}$ the contrary, recent studies suggested that NL may be beneficial in upper viral respiratory infectious diseases. In order to take stock of this issue, we conducted a short literature review to address 4 main questions:
\end{abstract}

nasal lavages, SARS-CoV-2, viruses, viral load, coronavirus infections, pandemics

\section{What Are the Potential Benefits of NL to COVID-19 Patients?}

Beneficial effects on nasal mucosal. Ions, $\mathrm{pH}$ and tonicity may influence epithelial cell function in vitro. Isotonic solutions with slightly alkaline $\mathrm{pH}$ optimize trophic and functional recovery of the respiratory epithelium. ${ }^{2}$ In chronic rhinosinusitis, saline solutions improve mucociliary clearance ${ }^{3}$ without altering commensal bacteria. ${ }^{4}$ These actions may aid recovery of the nasal epithelium after viral injury and reduce associated symptoms of rhinitis.

Direct antiviral effects. Recently, Ramalingam et al reported that antiviral activity against viral infections can be augmented by increasing availability of $\mathrm{NaCl}^{5}{ }^{5}$ Nasal lavages containing carrageenans, which are natural emulsifiers derived from red seaweed, seemed to reduce the Influenza A viral load in nasal secretions and positive effects on mucosal barrier function. ${ }^{6,7}$ Hendley and Gwaltney reported lower virus concentrations after saline NL in rhinovirus infections. ${ }^{8}$ Regarding severe acute respiratory syndrome coronavirus 2 (SARS-CoV-2), Carrouel et al found the use of a mouth rinses with local nasal applications that contain $\beta$-cyclodextrins combined with flavonoids agents reduce the viral load of saliva and nasopharyngeal microbiota, including potential SARS-CoV-2 carriage. ${ }^{9}$
The use of copper-enhanced NL seems to be efficient to decrease viral spread and contamination, especially regarding SARS-CoV-2. ${ }^{10,11}$ Human coronavirus $229 \mathrm{E}$ was rapidly inactivated on a range of copper alloys at low copper concentration, suggesting a specific antiviral effect. ${ }^{12,13}$ In fact, exposure to copper destroyed the viral genomes and irreversibly affected virus morphology, including disintegration of envelope and dispersal of surface spikes. ${ }^{14}$ Copper also inactivates SARS coronavirus, bacteria, and yeast in the air after 20 minutes of exposure. ${ }^{15} \mathrm{~A}$ recent study has proposed that the combination of copper, $\mathrm{N}$ acetylcysteine, colchicine, and nitric oxide with antiviral agents may be a treatment option for SARS-CoV-2-positive patients. ${ }^{16}$

Washing and reduction of viral load in enhancing recovery. Computational fluid dynamics studies demonstrate that all nasal regions are reached when using a head tilt position of $45{ }^{\circ} \mathrm{C}$ forward for $\mathrm{NL},{ }^{17}$ especially with large-volume irrigations, ${ }^{18}$

\footnotetext{
' COVID-19 Task Force of the Young-Otolaryngologists of the International Federations of Otorhinolaryngological Societies (YO-IFOS), Marseille, France

${ }^{2}$ Department of Otorhinolaryngology-Head and Neck Surgery, Aix Marseille University, APHM, IUSTI, La Conception University Hospital, Marseille, France

${ }^{3}$ Department of Human Anatomy and Experimental Oncology, Faculty of Medicine, UMONS Research Institute for Health Sciences and Technology, University of Mons (UMons), Mons, Belgium

${ }^{4}$ Department of Otolaryngology-Head \& Neck Surgery, Foch Hospital, School of Medicine, UFR Simone Veil, Université Versailles Saint-Quentin-enYvelines (Paris Saclay University), Paris, France

${ }^{5}$ King's College, London
}

Received: July 20, 2020; revised: July 23, 2020; accepted: July 27, 2020

\section{Corresponding Author:}

Thomas Radulesco, MD, PhD, MS, Department of Otorhinolaryngology-Head and Neck Surgery, La Conception University Hospital, I47 Bd Baille, I3005 Marseille, France.

Email: thomas.radulesco@ap-hm.fr 
suggesting good mechanical efficiency of NL in washing the nose.

Nasal mucosa have high viral loads and include cells expressing proteases responsible for virus entry (such as angiotensinconverting enzyme 2 and TMPRSS2 for SARS-CoV-2), ${ }^{19,20}$ The upper airway has shown to be a reservoir for descending bacterial or viral infection to the lung. ${ }^{21}$ The nose can be considered as a site of virus replication, accumulation, and human body entry. ${ }^{22}$ Interestingly, NL tends to decrease nasal viral loads and, therefore, could reduce systemic or bronchopulmonary dissemination. ${ }^{8}$ Nasal lavages are commonly used treatments in the upper respiratory tract infections and can decrease duration of illness in common cold. ${ }^{3,23,24}$

Given the potential benefits summarized above, nasal saline irrigation may enhance recovery in patients known to be infected with COVID-19. Patients are currently being recruited to a randomized controlled trial to evaluate the benefits to COVID-19 patients, although no results are yet available. $^{25}$

\section{What Are the Potential Benefits of NL to Personal Contacts/Healthcare Workers Caring for COVID-19 Patients?}

When properly performed, NL have shown to decrease household transmission in other viral disease. ${ }^{26}$ The potential direct antiviral actions and reduction in viral load have led to proposals that use in patients with COVID-19 may reduce risk of nosocomial transmission. It has been proposed that regular use of NL in COVID-19 patients may reduce risk of transmission to household contacts or Healthcare Workers (HCWs), particularly if used before aerosol-generating procedures (AGPs). ${ }^{27}$ It has also been suggested that HCWs involved in the care of COVID-19 patients could use NL with povidoneiodine before and after patient contact, particularly for highrisk procedures. ${ }^{27}$

In asking a patient or currently healthy $\mathrm{HCW}$ to perform an intervention aimed at protecting others, it is important to discuss potential side effects of the intervention.

\section{What Are the Potential Harms of NL to Patients With COVID-19?}

Risk of toxicity. Although nasal saline irrigation has been shown to have no detrimental effects on olfaction, additives to NL solutions may cause anosmia, which would be difficult to detect in trials of COVID-19 patients, where olfactory dysfunction is highly prevalent. A number of agents have been shown to cause anosmia if delivered intranasally, such as zinc gluconate and sinus surfactant solutions. ${ }^{28}$ Although the safety of povidone-iodine has been evaluated in vitro, at concentrations above $5 \%$ it is known to be ciliotoxic. ${ }^{29}$ Its use in mouthwash and nasal spray in COVID-19-infected patients prior to dental and other AGPs has been widely promoted in the absence of rigorous in vivo evaluation. ${ }^{7,30}$
Risk of bronchopulmonary dissemination. To date, no study suggested that NL is associated with lower respiratory disorders.

\section{What Are the Potential Harms of NL to Personal Contacts/HCWs Caring For COVID-1 9 Patients?}

Risk of droplet spread and surface contamination. Irrigation is likely to generate droplets potentially carrying viruses. Sinus irrigation devices, mostly composed by plastic, can harbor viruses for hours: van Doremalen et al showed that SARS$\mathrm{CoV}-2$ is very stable on plastic and remains viable up to 72 hours. ${ }^{12}$ As the COVID-19 status of most of patients using NL is unknown, specific measures should be undertaken to protect personal contacts or HCWs. ${ }^{31}$

\section{Protective measures.}

- Clean the inside and outside of the NL device thoroughly with soap and water. For a deeper clean of components of the device that come into contact with the nose, clean with $70 \%$ isopropyl alcohol or concentrated white vinegar, rinse, and then leave to it dry before next use. Some commercial products may be suitable for sterilization in the microwave but must be replaced if there is any sign of degradation of plastic components.

- Self-irrigation is important, avoiding viral exposure to others.

- Ventilate the room: being able to remain suspended in the air, small droplets were shown to permit SARSCoV-2 detection in ambient air for 3 hours. ${ }^{12}$ Guidelines on air exchanges per hour required for airborne contaminant removal have been edited by CDC. ${ }^{32}$

- Perform household cleaning, disinfection of high-touch surfaces, and hand hygiene. The United States Environmental Protection Agency and the CDC (Center for Disease Control and Prevention) published a list of recommended household disinfectants. ${ }^{33}$

Consistent with current guidance, these measures will help to limit viral spreading.

\section{Conclusion}

Taken together, these data suggest that NL can be continued during viral infection when respecting strict conditions of use and hygienic measures. Moreover, properly performed, largevolume NL with specific composition such as copper or povidone-iodine could limit viral contamination and spreading. In vitro, in vivo, and in silico studies must confirm these data.

\section{Authors' Note}

T.R. and J.R.L. are joint first authors. C.H. and J.M. are joint senior authors.

\section{Acknowledgments}

To Pr Vincent Couloigner and Dr Philippe Contencin. 


\section{Declaration of Conflicting Interests}

The author(s) declared no potential conflicts of interest with respect to the research, authorship, and/or publication of this article.

\section{Funding}

The author(s) received no financial support for the research, authorship, and/or publication of this article.

\section{ORCID iDs}

Thomas Radulesco (D) https://orcid.org/0000-0002-5939-5372

Jerome R. Lechien (D) https://orcid.org/0000-0002-0845-0845

Sven Saussez (D) https://orcid.org/0000-0002-3655-1854

\section{References}

\section{CONSULTATIONS ET TRAITEMENTS MEDICAMENTEUX} EN RHINOLOGIE EN CONTEXTE D'EPIDEMIE COVID-19. 2020. Accessed July 15, 2020. https://www.sforl.org/wp-content/ uploads/2020/03/AFR-SFORL-COVID-19-V2.pdf.

2. Bastier PL, Lechot A, Bordenave L, Durand M, de Gabory L. Nasal irrigation: from empiricism to evidence-based medicine. A review. Eur Ann Otorhinolaryngol Head Neck Dis. 2015; 132(5):281-285.

3. de Gabory L, Escabasse V, Boudard P, et al. Prospective, randomized, controlled, open-label study to compare efficacy of a mineral-rich solution vs normal saline after complete ethmoidectomy. Eur Arch Otorhinolaryngol. 2019;276(2):447-457.

4. Liu CM, Kohanski MA, Mendiola M, et al. Impact of saline irrigation and topical corticosteroids on the postsurgical sinonasal microbiota: topical therapies and the sinonasal microbiota. Int Forum Allergy Rhinol. 2015;5(3):185-190.

5. Ramalingam S, Cai B, Wong J, et al. Antiviral innate immune response in non-myeloid cells is augmented by chloride ions via an increase in intracellular hypochlorous acid levels. Sci Rep. 2018;8(1):13630. doi:10.1038/s41598-018-31936-y

6. Leibbrandt A, Meier C, König-Schuster M, et al. Iota-carrageenan is a potent inhibitor of influenza A virus infection. PLoS One. 2010;5(12):e14320. doi:10.1371/journal.pone.0014320

7. Ramezanpour M, Murphy J, Smith JLP, Vreugde S, Psaltis AJ. In vitro safety evaluation of human nasal epithelial cell monolayers exposed to carrageenan sinus wash. Int Forum Allergy Rhinol. 2017;7(12):1170-1177. doi:10.1002/alr.22021

8. Hendley JO, Gwaltney JM. Viral titers in nasal lining fluid compared to viral titers in nasal washes during experimental rhinovirus infection. J Clin Virol. 2004;30(4):326-328.

9. Carrouel F, Conte MP, Fisher J, et al. COVID-19: a recommendation to examine the effect of mouthrinses with $\beta$-cyclodextrin combined with citrox in preventing infection and progression. J Clin Med. 2020;9(4):1126.

10. Huang S, Constant S, De Servi B, et al. In vitro safety and performance evaluation of a seawater solution enriched with copper, hyaluronic acid, and eucalyptus for nasal lavage. Med Devices (Auckl). 2019;12:399-410.

11. Radulesco T, Lechien JR, Chiesa-Estomba CM, et al. Copper enhanced nasal saline irrigations: a safe potential treatment and protective factor for COVID-19 infection? Rhinol Online. 2020; $3(3): 87-88$.
12. van Doremalen N, Bushmaker T, Morris DH, et al. Aerosol and surface stability of SARS-CoV-2 as Compared with SARS-CoV-1. $N$ Engl J Med. 2020;382(16):1564-1567. doi:10.1056/NEJMc 2004973

13. Borkow G, Gabbay J. Copper as a biocidal tool. Curr Med Chem. 2005;12(18):2163-2175. doi:10.2174/0929867054637617

14. Warnes SL, Little ZR, Keevil CW. Human coronavirus 229E remains infectious on common touch surface materials. mBio. 2015;6(6):e01697-15. doi:10.1128/mBio.01697-15

15. He H, Dong X, Yang M, et al. Catalytic inactivation of SARS coronavirus, Escherichia coli and yeast on solid surface. Catal Commun. 2004;5(3):170-172. doi:10.1016/j.catcom.2003.12. 009

16. Andreou A, Trantza S, Filippou D, Sipsas N, Tsiodras S.COVID19: the potential role of copper and n-acetylcysteine (NAC) in a combination of candidate antiviral treatments against SARSCoV-2. Vivo Athens Greece. 2020;34(3 suppl):1567-1588.

17. Inthavong $\mathrm{K}, \mathrm{Ma} \mathrm{J}$, Shang $\mathrm{Y}$, et al. Geometry and airflow dynamics analysis in the nasal cavity during inhalation. Clin Biomech (Bristol, Avon). 2019;66:97-106. doi:10.1016/j.clinbiomech.2017.10.006

18. de Gabory L, Reville N, Baux Y, Boisson N, Bordenave L. Numerical simulation of two consecutive nasal respiratory cycles: toward a better understanding of nasal physiology: simulation of nasal physiology. Int Forum Allergy Rhinol. 2018;8(6):676-685.

19. Hoffmann M, Kleine-Weber H, Schroeder S, et al. SARSCoV-2 Cell entry depends on ACE2 and TMPRSS2 and Is blocked by a clinically proven protease inhibitor. Cell. 2020; 181(2):271-280.e8.

20. Zou L, Ruan F, Huang M, et al. SARS-CoV-2 Viral load in upper respiratory specimens of infected patients. $N$ Engl J Med. 2020; 382(12):1177-1179.

21. Fothergill JL, Neill DR, Loman N, Winstanley C, Kadioglu A. Pseudomonas aeruginosa adaptation in the nasopharyngeal reservoir leads to migration and persistence in the lungs. Nat Commun. 2014;5:4780. doi:10.1038/ncomms5780

22. Butowt R, Bilinska K.SARS-CoV-2: Olfaction, Brain infection, and the urgent need for clinical samples allowing earlier virus detection. ACS Chem Neurosci. 2020;11(9):1200-1203. doi:10. 1021/acschemneuro.0c00172

23. Cabaillot A, Vorilhon P, Roca M, Boussageon R, Eschalier B, Pereirad B. Saline nasal irrigation for acute upper respiratory tract infections in infants and children: a systematic review and metaanalysis. Paediatr Respir Rev. 2020;S1526-0542(20)30016-6. doi:10.1016/j.prrv.2019.11.003

24. King D, Mitchell B, Williams CP, Spurling GK. Saline nasal irrigation for acute upper respiratory tract infections. Cochrane Database Syst Rev. 2015;(4):CD006821. doi:10.1002/14651858. CD006821.pub3

25. Participant Information Sheet. 2020. Accessed July 15, 2020. https://www.ed.ac.uk/files/atoms/files/elvis_covid-19_partici pant_information_sheet_v4.0_01june2020.pdf.

26. Ramalingam S, Graham C, Dove J, Morrice L, Sheikh A. A pilot, open labelled, randomised controlled trial of hypertonic saline nasal irrigation and gargling for the common cold. Sci Rep. 2019;9(1):1015. doi:10.1038/s41598-018-37703-3 
27. Mady LJ, Kubik MW, Baddour K, Snyderman CH, Rowan NR. Consideration of povidone-iodine as a public health intervention for COVID-19: utilization as « Personal Protective Equipment » for frontline providers exposed in high-risk head and neck and skull base oncology care. Oral Oncol. 2020;105:104724.

28. Davidson TM, Smith WM. The Bradford hill criteria and zincinduced anosmia: a causality analysis. Arch Otolaryngol Head Neck Surg. 2010;136(7):673-676.

29. Kim JH, Rimmer J, Mrad N, Ahmadzada S, Harvey RJ. Betadine has a ciliotoxic effect on ciliated human respiratory cells. J Laryngol Otol. 2015;129(supp1 1):S45-S50. doi:10.1017/ S0022215114002746
30. Challacombe SJ, Kirk-Bayley J, Sunkaraneni VS, Combes J. Povidone iodine. Br Dent J. 2020;228(9):656-657. doi:10.1038/ s41415-020-1589-4

31. Should You Still Rinse Your Sinuses During The COVID-19 Outbreak? 2020. Accessed July 15, 2020. https:/www.henryford.com/ blog/2020/03/should-you-rinse-your-sinuses-during-covid.

32. Guidelines for Environmental Infection Control in Health-Care Facilities. 2003. Accessed July 15, 2020. https:/www.cdc.gov/ infectioncontrol/guidelines/environmental/appendix/air.html.

33. List N: Disinfectants for Use Against SARS-CoV-2 (COVID-19). Accessed July 15, 2020. https://www.epa.gov/pesticide-registra tion/list-n-disinfectants-use-against-sars-cov-2-covid-19. 